\title{
RESEARCH
}

Open Access

\section{Relation between personality dimensions and symptomatology of depression in skin cancer patients}

\author{
ML Ramírez-de los Santos', A López-Navarro', S Ramírez-de los Santos', JM Guzmán-Flores', \\ AL Pereira-Suárez ${ }^{2}$ and El López-Pulido ${ }^{1 *}$
}

\begin{abstract}
Background: Environmental psychological factors such as mood states can modify and trigger an organic response; depressive disorder is considered a risk factor for oncological development, leading to alterations both in the genesis and in the progression of the disease. Some authors have identified that personality relates to mood since a high score in neuroticism is associated with intense and long-lasting emotions of stress and therefore with the development of depressive behaviors. The objective of this study was to analyze the relationship between personality and depression in skin cancer patients.

Methods: A total of forty-seven clinically and histopathologically diagnosed patients were scheduled for an hourlong interview, during which they provided informed consent and sociodemographic information. The psychological questionnaires applied were the revised Eysenck Personality Questionnaire and the clinical questionnaire for the diagnosis of the depressive syndrome.

Results: The patient's mean age was 66.5 years $(S D \pm 12.4)$ and the majority were diagnosed with basal cell carcinoma (70.2\%). The frequency of anxious/depressive symptoms was $42.5 \%$, with an increase in depression scores in the female gender $(p<0.001)$. Furthermore, a difference was found in the neuroticism dimension related to gender, with higher values in women $(p=0.002)$. Depressive symptomatologic portraits were correlated with the dimensions of neuroticism $(p<0.001, r=0.705)$, psychoticism $(p=0.003, r=0.422)$ and lying $(p=0.028, r=-0.321)$.

Conclusions: Our results support the hypothesis that personality dimensions are related to the presence of anxiety/ depressive symptomatology in patients with skin cancer, especially in the female gender. Highlighting the need for future research that delves into the implications at the psychological level, the quality of life, and the biological mechanisms that link personality and depressive symptoms in the development and evolution of skin cancer.
\end{abstract}

Keywords: Personality dimensions, Anxiety, Depression, Skin cancer

\footnotetext{
*Correspondence: edgar.lopez@cualtos.udg.mx

${ }^{1}$ Centro Universitario de los Altos, Universidad de Guadalajara, Road to

Yahualica $7.5 \mathrm{Km}$, Jalisco 47600 Tepatitlan de Morelos, Mexico

Full list of author information is available at the end of the article
}

(c) The Author(s). 2021 Open Access This article is licensed under a Creative Commons Attribution 4.0 International License, which permits use, sharing, adaptation, distribution and reproduction in any medium or format, as long as you give appropriate credit to the original author(s) and the source, provide a link to the Creative Commons licence, and indicate if changes were made. The images or other third party material in this article are included in the article's Creative Commons licence, unless indicated otherwise in a credit line to the material. If material is not included in the article's Creative Commons licence and your intended use is not permitted by statutory regulation or exceeds the permitted use, you will need to obtain permission directly from the copyright holder. To view a copy of this licence, visit http://creativecommons.org/licenses/by/4.0/. The Creative Commons Public Domain Dedication waiver (http://creativecommons.org/publicdomain/zero/1.0/) applies to the data made available in this article, unless otherwise stated in a credit line to the data. 


\section{Background}

The personality plays an important role not only in the reaction to stressful events, but it also influences the presence of various types of predominant emotions in the person. Such is the case of neuroticism where high levels of it have been identified as a risk factor for the development of depressive disorder [ 1 , $2]$. Depression occurs in various forms and contains a wide range of symptoms characterized mainly by anhedonia and low moods [3, 4]. It is a public health problem, reported as the third cause of disability worldwide and its presence is associated with various chronic inflammatory diseases [5-8].

Depression in cancer patients is very common and its incidence rate is up to three times higher than in the general population, it has been reported to affect more than $10 \%$ of patients and to a greater extent in women [9-12]. However, despite being frequent, on repeated occasions, depressive symptoms in clinical practice are not identified. Concerning skin cancer, a high prevalence of depressive symptoms has been observed in patients with basal cell carcinoma (BCC) because the quality of life of individuals after the diagnosis of the disease declines considerably [13-15]. Also, a higher prevalence of anxiety and depression has been identified in patients with advanced melanoma compared to those with early disease [16].

One psychosocial construct inviting debate is that of personality and its possible role in cancer outcomes. As personality traits are believed to be stable, they would seem more as transient states in the prediction of disease progression over longer periods $[17,18]$. In patients with squamous cell carcinoma (SCC), a relationship has been observed with scores of the neuroticism dimension [19, 20]. Regarding melanoma skin cancer, a possible association with the extraversion and psychoticism personality dimensions has been identified [21].

The objective of this study is to describe personality dimensions and the prevalence of anxiety or depression symptomatology in a skin cancer population. Following, we analyze the data looking for a possible relation between the personality and depression scores.

\section{Methods}

\section{Study population}

The sample consisted of forty-seven Mexican skin cancer patients who attend a private dermatological consultation. All patients were included at an early stage (stage I) according to the American Joint Commission on Cancer (AJCC) TNM system. Since BCC, SCC, and mixed carcinoma no presented high-risk features, tumors were less than $2 \mathrm{~cm}$ and have not spread to nearby lymph nodes or organs. Melanomas were localized, smaller than $1 \mathrm{~mm}$ in depth and not ulcerated. The sampling method used was non-probabilistic for convenience, limiting the selection of subjects by geographical proximity and that they met the inclusion criteria, achieving a homogeneous population to minimize the required number of participants. Requirements to be part of the project included age of 18 years or older, clinical, and histopathological diagnosis of skin cancer, and sign the informed consent. Within the exclusion criteria, pregnancy, the presence of some fungal disease or other types of concomitant acute infection, and other inflammatory diseases were considered. The study was developed according to the guidelines of the Helsinki Declaration World Medical Association (Helsinki Declaration World Medical Association, 2013) with the approval of the Clinic department and institutional bioethics committee at the Guadalajara University (CUA/CEI/DOBI008/2021).

\section{Data collection procedure}

Clinically and histopathologically diagnosed patients were scheduled for an hour-long interview, during which they provided informed consent and sociodemographic information. The psychological questionnaires were also applied: EPQ-R (full version) and the clinical questionnaire for the diagnosis of the depressive syndrome.

\section{Measures}

Sociodemographic information. Information related to age, gender, marital status, employment status was collected along with medical information as the diagnosis, body site, and history of non-melanoma skin cancer (NMSC).

\section{Personality dimensions}

The EPQ-R questionnaire was used to measure the personality dimensions: extraversion (E), neuroticism $(\mathrm{N})$, psychoticism (P), and social desirability or lying (L). It consists of 83 items that correspond to four dimensions with dichotomous responses. The questionnaire is interpreted based on each of the dimensions, which yield a score as they increase or decrease, indicating greater or lesser presence or strength of that personality. The Cronbach coefficient considered to be a measure of scale reliability was calculated for our sample with a value of $\alpha=0.75$, indicating acceptable internal consistency [22].

\section{Depression}

The clinical questionnaire was used to evaluate the symptoms and diagnose the mood: normal, anxiety reaction, depression of medium intensity, and severe depression [23]. It consists of 20 items, corresponding to common symptoms present in depression, with responses on a Likert-type scale with values from 1 to 4 according to intensity, obtaining minimum scores of 20 
and a maximum of 80 . The results are interpreted based on the scores, from 20 to 35 points are considered normal moods, from 36 to 45 are identified as patients with anxiety reactions, from 46 to 65 are considered as patients with depressive symptoms of medium intensity, and finally, if the patient presents scores of $66-80$ it is considered that he/she presents a severe depressive state. Regarding the reliability of the questionnaire, Cronbach's alpha was calculated for our sample and a value of $\alpha=$ 0.86 was obtained, suggesting a good internal consistency [22].

\section{Data analysis}

Descriptive statistics were calculated for sociodemographic data, personality dimensions scores, and depression frequency. The influence of gender and age on personality and depression was determined using the Student T-test or Mann-Whitney U test. Other sociodemographic and clinical variables such as marital status, occupation, phototype, and skin cancer diagnosis were evaluated by the Kruskal-Wallis test and one-way ANOVA. Finally, Correlations were determined by Pearson or Spearman coefficients to examine the relationship between the EPQ-R and depression questionnaire measures. The analyses were conducted using SPSS 22 software with a significance level set at $p<0.05$.

\section{Results}

\section{Sociodemographic and clinical characteristics}

According to the sociodemographic data, the mean age of the patients included was 66.5 years (SD \pm 12.4). Patients of both genders were incorporated in a similar proportion. Regarding marital status, more than half of them were married people $(72.4 \%)$, in the interview, the participants referred to various occupations, one of the most cited was that of a housewife (48.9\%). About the Fitzpatrick skin phototype scale (FST), most skin cancer patients presented II and III phototypes (93.7\%). On the other hand, with the support of both private practice and the Dermatological Institute of Jalisco "Dr. José Barba Rubio", certified by the Mexican Council of Dermatology and The International Committee for Dermatopathology, it was identified that $70.2 \%$ of the patients presented BCC, followed by SCC (23.4\%). Meanwhile, melanoma (4.3\%) and mixed carcinoma (2.1\%). All these malignant neoplasms were mainly located in the head and neck area (68.1\%) and the recurrence reported to date occurs in almost a fifth of the population captured (19.1\%). Table 1 shows the complete values of each of the sociodemographic variables mentioned above.
Table 1 Demographic and clinical characteristics of the study population

\begin{tabular}{|c|c|c|c|}
\hline Characteristic & & $n$ & Percentage \\
\hline \multirow[t]{3}{*}{ Age } & $30-59$ & 10 & 21.3 \\
\hline & $60-90$ & 37 & 78.7 \\
\hline & Total & 47 & 100 \\
\hline \multirow[t]{3}{*}{ Gender } & Female & 26 & 55.3 \\
\hline & Male & 21 & 44.7 \\
\hline & Total & 47 & 100 \\
\hline \multirow[t]{5}{*}{ Marital status } & Single & 7 & 14.9 \\
\hline & Married & 34 & 72.4 \\
\hline & Divorced & 1 & 2.1 \\
\hline & Widowed & 5 & 10.6 \\
\hline & Total & 47 & 100 \\
\hline \multirow[t]{5}{*}{ Occupation } & Farm workers & 13 & 27.7 \\
\hline & Home maker & 23 & 48.9 \\
\hline & Retired & 7 & 14.9 \\
\hline & Other & 4 & 8.5 \\
\hline & Total & 47 & 100 \\
\hline \multirow[t]{5}{*}{ Fitzpatrick Phototypes } & 1 & 2 & 4.2 \\
\hline & $\|$ & 24 & 51.2 \\
\hline & III & 20 & 42.5 \\
\hline & IV & 1 & 2.1 \\
\hline & Total & 47 & 100 \\
\hline \multirow[t]{5}{*}{ Diagnosis of skin cancer } & Melanoma & 2 & 4.3 \\
\hline & $\mathrm{BCC}$ & 33 & 70.2 \\
\hline & SCC & 11 & 23.4 \\
\hline & $\mathrm{BCC} / \mathrm{SCC}$ & 1 & 2.1 \\
\hline & Total & 47 & 100 \\
\hline \multirow[t]{5}{*}{ Location } & Head/Neck & 32 & 68.2 \\
\hline & Back/chest & 0 & 0 \\
\hline & Limbs (arms/legs) & 2 & 4.2 \\
\hline & Missing & 13 & 27.6 \\
\hline & Total & 47 & 100 \\
\hline \multirow[t]{4}{*}{ Recurrence } & Yes & 9 & 19.1 \\
\hline & No & 28 & 59.6 \\
\hline & Missing & 10 & 21.3 \\
\hline & Total & 47 & 100 \\
\hline
\end{tabular}

Notes: $B C C$ basal cell carcinomas, $S C C$ squamous cell carcinomas

Personality profile and symptomatology of depression Regarding the psychological questionnaire (EPQ-R) which includes the personality dimensions neuroticism, extraversion, psychoticism, and lying or dissimulation was applied to the patients. In the first place, the number of items corresponding to the dimensions was identified, as well as the minimum scores and maximums obtained. After, the mean and standard deviation were 
calculated which corresponded to those reported in studies from the same test in the Spanish population. However, an increase of the L dimension means scores to the mean used by the instrument was identified. The complete values are observed in Table 2 .

Relating to the analysis of the distribution by frequencies of the questionnaire for the diagnosis of depressive symptoms, they were classified as normal patients when they did not show symptoms, anxiety reaction, medium intensity depression, or severe state of depression. Where we find the presence of depressive symptomatology in almost half of the patients (42.5\%), corresponding to anxiety reaction and medium intensity depression, as shown in Table 3.

Later we evaluate the influence of gender and age on the personality and depression scores. Where it was observed that the female gender presents higher values in the dimension of $\mathrm{N}(p=0.002)$, while the dimensions of $\mathrm{E}, \mathrm{P}$, and $\mathrm{L}$ were perceived as similar both in men as in women. When making comparisons by age groups, elevated values of $\mathrm{L}$ dimension are observed in the 60-90 age group $(p=0.049)$. When analyzing the depressive symptomatology about gender and age, a significant association is identified with the increase in depression scores in the female gender $(p<0.001)$. Also, we can observe trends with higher values in the scores in the 30 59 age group. The complete values are observed in Table 4. Variables such as marital status, occupation, phototype or even the type of skin cancer were not associated with significant differences in personality or depression scores $(p>0.05)$.

Finally, the relationship between the scores of the dimensions of the EPQ-R questionnaire and depression scores was evaluated. The results show significant correlations between anxious and depressive symptomatologic portraits with most of the personality dimensions except $\mathrm{E}$, obtaining positive correlations with $\mathrm{N}$ and $\mathrm{P}$ dimensions $(p<0.001, \mathrm{r}=0.705$ and $p=0.003, \mathrm{r}=0.422$ ), while a negative correlation was observed with dimension $\mathrm{L}(p=0.028, \quad \mathrm{r}=-$ 0.321). Another interesting result were the correlations between the different personality dimensions $\mathrm{E}$ with $\mathrm{P}(p=0.018, \mathrm{r}=-343), \mathrm{N}$ with $\mathrm{P}(p<0.01, \mathrm{r}=$ $0.468)$ and $\mathrm{P}$ with $\mathrm{L}(p=0.026, \mathrm{r}=-0.325)$. The results are detailed in Table 5 .

Table 2 Skin cancer patients scores on the EPQ-R

\begin{tabular}{llllll}
\hline Variable & Items & Mean & SD & Minimum & Maximum \\
\hline Extraversion & 19 & 11.6 & 4.7 & 3 & 19 \\
Neuroticism & 23 & 11.8 & 6.6 & 0 & 23 \\
Psychoticism & 23 & 6.9 & 2.6 & 0 & 14 \\
Lie & 18 & 14.3 & 2.8 & 5 & 18 \\
\hline
\end{tabular}

Note: SD Standard deviation
Table 3 Diagnosis of depressive symptomatology in skin cancer patients

\begin{tabular}{lll}
\hline Diagnostic & Frequency & Percentage \\
\hline Normal & 27 & 57.4 \\
Anxiety reaction & 11 & 23.4 \\
Medium intensity depression & 9 & 19.1 \\
Severe state of depression & 0 & 0 \\
Total & 47 & 100 \\
\hline
\end{tabular}

\section{Discussion}

Skin cancer is characterized by being a disease in which there is an abnormal growth of the cells of the skin tissues. Represents the most common cancer worldwide, exceeding the prevalence of other types of malignant neoplasms combined. It is classified in melanoma and non-melanoma skin cancer (NMSC), the latter encompassing keratinocyte carcinomas which can be subclassified into BCC and SCC. NMSC represents $99 \%$ of the total of skin neoplasms [24-26]. Most of the patients included in our study present BCC (70.2\%), followed by SCC and with very few patients with mixed carcinoma and melanoma. This coincides with various registries that show that the prevalence is higher in BCC than in any other type of skin cancer [27, 28]. In addition, a higher percentage of skin cancer has been reported in men compared to women, with values ranging from 60 to $63 \%[29,30]$. In the study, a similar amount was presented in both genders; the differences may be influenced by the type of sampling and the number of patients included.

It has been previously reported that the incidence of NMSC increases with age, the probability of presenting BCC / SCC with each year of age increases up to $10 \%$, while in melanoma only $4 \%$, this could be since the older the immune system is less efficient in the resolution of some DNA damage [31]. Based on the results of the present study, it was identified that the mean age of patients with skin cancer is 66.5 years and that the age group with the highest percentage is $60-90$ years. These results are like various studies carried out in a European population, with means of 63 years of age in patients with BCC and 64.7 years for patients with SCC [28, 29]. While the age range with the highest percentages has been described in patients with skin cancer is 61 to 70 years [32, 33].

Although, there are previous studies that refer to an occupation as a risk factor, finding a higher prevalence in the work of welders, specialized farmers, miners, and stonemasons in patients with BCC. While in those with SCC, occupations are to a greater extent than involved direct contact with livestock, construction workers, stationary motor operators, and bricklayers [28, 30]. Meanwhile, in our study, the highest percentage of patients 
Table 4 Personality dimensions, depression, and the influence of age and gender

\begin{tabular}{|c|c|c|c|c|c|c|c|c|}
\hline \multirow[b]{3}{*}{ Measure } & \multirow{2}{*}{\multicolumn{2}{|c|}{ Female }} & \multirow{2}{*}{\multicolumn{2}{|c|}{ Male }} & \multicolumn{4}{|l|}{ Age (years) } \\
\hline & & & & & \multicolumn{2}{|l|}{ 30-59 } & \multicolumn{2}{|l|}{$60-90$} \\
\hline & Media \pm SD & Median & Media \pm SD & Median & Media \pm SD & Median & Media \pm SD & Median \\
\hline Depression total score & $39.8 \pm 11.7 * * \neq$ & 37.5 & $29.3 \pm 5.5$ & 29.0 & $38.7 \pm 12.6$ & 37.0 & $34.18 \pm 10.1$ & $33.0 t$ \\
\hline \multicolumn{9}{|l|}{$E P Q-R$ scores } \\
\hline Extraversion & $12.1 \pm 4.4 \ddagger$ & 13.0 & $11.1 \pm 5.1$ & 11.0 & $11.2 \pm 4.8$ & 10.0 & $11.8 \pm 4.7 \ddagger$ & 13.0 \\
\hline Neuroticism & $14.8 \pm 5.9$ & $16.0^{*}+$ & $8.0 \pm 5.3$ & 8.0 & $11.9 \pm 8.5$ & 11.5 & $11.7 \pm 6.1 \neq$ & 10.0 \\
\hline Psychoticism & $7.5 \pm 2.4 \ddagger$ & 7.0 & $6.2 \pm 2.7$ & 6.0 & $6.3 \pm 2.4$ & 6.5 & $7.1 \pm 2.7 \neq$ & 7.0 \\
\hline Lie & $14.4 \pm 3.1$ & $14.5+$ & $14.1 \pm 2.5$ & 15.0 & $12.5 \pm 3.4$ & 12.5 & $14.7 \pm 2.4$ & $15.0^{*} \dagger$ \\
\hline
\end{tabular}

Notes: SD Standard deviation; † Mann-Whitney U test, $\neq$ Student's t-test; ${ }^{*} p<.05,{ }^{* *} p<.01$

reported being housewives. Other factors that could be influencing are the FST and the degree of solar exposure; The latter being one of the factors with the greatest impact on human skin and is particularly important in terms of sensitivity to UV-induced DNA damage $[34,35]$. As in previous studies, the results of this study identified most of the participants with FST II and III. FST is one of the factors identified with the development of skin cancer, finding a higher prevalence in populations with light skin phototypes. In addition, it has been widely described that the location of skin cancer lesions is to a greater extent in photo-exposed areas such as the head, neck, cheeks, nose, etc. [32, 33]. These data agree with those found in the study population included, finding that $68.2 \%$ of skin cancers are in the head or neck region.

Regarding the results obtained for the personality dimensions. Taking into consideration the measures provided by the EPQ-R manual applied in healthy population for the different dimensions with means of $12.7 \pm 4.0$ for $\mathrm{E}, 13.4 \pm 5.4$ for $\mathrm{N}, 5.7 \pm 3.5$ for $\mathrm{P}$, and $8.4 \pm 3.8$ for $\mathrm{L}$. We observe similar values except for $\mathrm{L}$, which is above the mean. However, this differential behavior may be due to the age of the subjects included, as is previously reported that $\mathrm{L}$ scores are higher in ages between 40 to 60 years. However, it is not the only dimension that has been associated with age, $\mathrm{E}$ is also associated even though it is inversely associated [36, 37].

The link between personality and cancer development has not yet been demonstrated, with conflicting results in different types of tumors. According to the results of some investigations where personality was evaluated in patients with lung, colon, breast, prostate, skin, leukemia, and lymphoma cancers, no associations were obtained regarding the risk of their development [20, 38]. However, there are reports of male patients with lung cancer presenting higher extraversion scores and lower neuroticism scores [39]. Others, for their part, have found in cancer survivors patients present higher levels of psychoticism and neuroticism with low levels of extraversion, although without significant differences [40]. Although the absence of a control group eliminates the possibility of inquiring about the possible connection between personality and the diagnosis of skin cancer in the subjects included. As in the studies mentioned above, our results reveal the influence of gender by obtaining higher values in the dimension of $\mathrm{N}$ in the female gender. The foregoing has been previously described in open populations, showing higher levels of $\mathrm{N}$ in women compared to men [41].

Environmental psychological factors such as mood states can modify and trigger an organic response [42, 43]. Personality relates to mood; some authors identify high scores in neuroticism associated with intense and long-lasting emotions of stress and therefore with the development of depressive behaviors [44]. It has been observed that cancer patients present comorbidities with psychological illnesses such as depressive disorder, even being considered as a risk factor for oncological development, leading to alterations both in the genesis and in the progression of the disease $[3,10,45]$. In addition, it has been documented that in older adults the presence

Table 5 Correlations for measures of personality and depression in patients

\begin{tabular}{|c|c|c|c|c|c|}
\hline Measure & 1 CQDD & $2 \mathrm{EPQ}-\mathrm{E}$ & 3 EPQ-N & 4 EPQ-P & $5 \mathrm{EPQ}-\mathrm{L}$ \\
\hline 1.Questionnaire for depression (CQDD) & $(0.86) \mathrm{a}$ & & & & \\
\hline 2. EPQ-Extraversion (EPQ-E) & $-0.172 \neq$ & $(0.84) \mathrm{a}$ & & & \\
\hline 3. EPQ-Neuroticism (EPQ-N) & $0.705^{* *}+$ & $-0.118 t$ & $(0.91) \mathrm{a}$ & & \\
\hline 4. EPQ- Psychoticism (EPQ-P) & $0.422^{* *} \neq$ & $-0.343^{*} \neq$ & $0.468^{* *} t$ & $(0.49)$ a & \\
\hline 5. EPQ-Lie (EPQ-L) & $-0.321^{*} \neq$ & $0.111 \neq$ & $-0.246+$ & $-0.325^{*} \neq$ & $(0.68) \mathrm{a}$ \\
\hline
\end{tabular}

Notes: $\dagger$ Pearson's $r$ or ₹ Spearman's correlation coefficients; a Cronbach's alpha; ${ }^{*} p<.05,{ }^{* *} p<.01$. Numbers $1-5$ correspond to the five measures listed 
of this disorder is associated with increased neuroticism in cancer survivors [46-48].

Measures of anxiety and depression and fear of cancer and negative associations with quality of life and emotional well-being in patients with cutaneous melanoma, especially in the female gender [16, 21, 49]. Similarly, in patients with $\mathrm{BCC}$, a positive association with the presence of depression has been recorded [17]. Although NMSC places a greater burden of symptoms on patients than melanoma, the psychological impact of melanoma is higher [50]. Our results coincide with previous studies by identifying that more than a third of patients with skin cancer show anxiety/depressive symptoms. Also, we found that there is a significant relationship between depressive symptomatology scores and female gender. These results are highly relevant when knowing that depression is associated with just over half of the incidence of suicides, in addition to the fact that there are studies that mention a high prevalence of suicides in female patients with NMSC, it is commented that the deforming capacity of the disease as the main reason $[27,51]$. Therefore, the detection and treatment of the disease in early stages acquires greater relevance in terms of skin cancer resolution and the psychological impact. Overall, patients who underwent dermatologic surgery on the face reported a low level of psychosocial distress [52].

Subsequently, we encounter that there are positive correlations between the scores for the anxious/depressive symptoms and the personality dimensions $\mathrm{N}$ and $\mathrm{P}$. Something that has also been mentioned in previous studies where high levels of neuroticism can generate vulnerability to depressive symptoms. In addition, psychoticism has been shown as a predictor of depressive symptoms in breast cancer survivors [53, 54]. Furthermore, we observed positive correlations between the dimensions of $\mathrm{N}$ and $\mathrm{P}$ which have not been found in the reviewed literature. However, it has been identified that high levels of both $\mathrm{N}$ and $\mathrm{P}$ are related to negative coping responses to stress and suicidal ideation $[37,55,56]$. A negative correlation between anxiety/depression and the $\mathrm{L}$ dimension scores was also found, people with high $\mathrm{L}$ scores are related to the presence of psychiatric disorders such as depression and schizophrenia [36, 57].

Limitations of this study include its cross-sectional nature and the relatively small number of subjects studied. Therefore, we believe that further studies are required to confirm our results.

\section{Conclusions}

Our study reinforced the high prevalence of $\mathrm{BCC}$ within the cases of skin cancer, the vulnerability according to age, and the influence of the phototype. On the other hand, the results obtained support the hypothesis that personality dimensions are related to the presence of anxiety/depressive symptomatology in patients with skin cancer, especially in the female gender. Highlighting the need for future research that delves into the implications at the psychological level, quality of life and the biological mechanisms that link personality and depressive symptoms in the development and evolution of skin cancer.

\section{Acknowledgments \\ The authors offer their thanks to the subjects included in this study for their participation.}

\section{Authors' contributions}

Project designs correspond to LPEI and LNA. Diagnosis, Recruitment, and data acquisition from patients were performed by RSML, LNA, and RSS. GFJM, PSAL, and LPEI designed the methods and perform data analysis. RSML and LPEI prepared and edited the manuscript. All authors reviewed and approved the final version of the manuscript.

\section{Funding}

Not applicable.

Availability of data and materials

Detailed data are available from the corresponding author upon request.

\section{Declarations}

Ethics approval and consent to participate

This study was approved by the Clinic department and institutional bioethics committee at the Guadalajara University (CUA/CEI/DOBI008/2021). Written informed consent was obtained from all participants before their enrollment in the study.

\section{Consent for publication}

Participants accept the diffusion of results through the confidentiality agreement. Information related to the identity of the subjects is omitted.

\section{Competing interests}

The authors declare no potential conflicts of interest to the research, authorship, and publication of this article.

\section{Author details}

${ }^{1}$ Centro Universitario de los Altos, Universidad de Guadalajara, Road to Yahualica $7.5 \mathrm{Km}$, Jalisco 47600 Tepatitlan de Morelos, Mexico. ${ }^{2}$ Centro Universitario de Ciencias de la Salud, Universidad de Guadalajara, Guadalajara, Jalisco, Mexico.

Received: 20 August 2021 Accepted: 20 September 2021

Published online: 12 October 2021

\section{References}

1. Golimbet VE, Alfimova MV, Korovaitseva GI, Lezheiko TV. Analysis of the association of interleukin 4 and interleukin 10 gene variants with basic personality traits. Mol Biol. 2016;50(6):839-44. https://doi.org/10.1134/S002 6893316060054

2. Allan NP, Cooper D, Oglesby ME, Short NA, Saulnier KG, Schmidt NB. Lowerorder anxiety sensitivity and intolerance of uncertainty dimensions operate as specific vulnerabilities for social anxiety and depression within a hierarchical model. J Anxiety Disord. 2018;53:91-9. https://doi.org/10.1016/j. janxdis.2017.08.002.

3. Chang HY, Keyes KM, Mok Y, Jung KJ, Shin YJ, Jee SH. Depression as a risk factor for overall and hormone-related cancer: the Korean cancer prevention study. J Affect Disord. 2015;173:1-8. https://doi.org/10.1016/j.ja d.2014.10.064.

4. Park LT, Zarate CA. Depression in the primary care setting. N Engl J Med. 2019;380(6):559-68. https://doi.org/10.1056/NEJMcp1712493.

5. Campayo A, De Jonge $P$, et al. Depressive disorder and incident diabetes mellitus: the effect of characteristics of depression. Am J Psychiatr. 2010; 167(5):5-588. https://doi.org/10.1176/appi.ajp.2009.09010038. 
6. Pan A, Sun Q, Okereke OI, Rexrode KM, Hu FB. Depression and risk of stroke morbidity and mortality: a meta-analysis and systematic review. JAMA. 2011; 306(11):1241-9. https://doi.org/10.1001/jama.2011.1282.

7. Patten SB, Williams JVA, Lavorato, et al. Patterns of association of chronic medical conditions and major depression. Epidemiol Psychiatr Sci. 2018; 27(1):42-50.

8. Schmidt FM, Sander C, Minkwitz J, Mergl R, Dalton B, Holdt LM, et al. Serum markers of inflammation mediate the positive association between neuroticism and depression. Front Psychiatr. 2018;9:609. https://doi.org/1 0.3389/fpsyt.2018.00609.

9. Adjei Boakye E, Osazuwa-Peters N, Mohammed KA, Challapalli S, Buchanan $P$, Burroughs TE, et al. Prevalence and factors associated with diagnosed depression among hospitalized cancer patients with metastatic disease. Soc Psychiatry Psychiatr Epidemiol. 2020;55(1):15-23. https://doi.org/10.1007/ s00127-019-01763-1.

10. Mayer S, Teufel M, Schaeffeler $\mathrm{N}$, et al. The need for psycho-oncological support for melanoma patients: Central role of patients' self-evaluation. Medicine. 2017;96(37):e7987. https://doi.org/10.1097/MD.0000000000007987.

11. Nikendei C, Wild B, Terhoeven V, et al. Depression profile in cancer patients and patients without a chronic somatic disease. Psycho-oncology. 2018; 27(1):83-90. https://doi.org/10.1002/pon.4465.

12. Smith HR. Depression in cancer patients: pathogenesis, implications and treatment (review). Oncol Lett. 2015;9(4):1509-14. https://doi.org/10.3892/ ol.2015.2944.

13. Laurence B, Mould-Millman NK, Nero KE, et al. Depression and hospital admission in older patients with head and neck cancer: analysis of a national healthcare database. Gerodontology. 2017;34(2):284-7. https://doi. org/10.1111/ger.12247.

14. Sampogna F, Paradisi A, lemboli ML, Ricci F, et al. Comparison of quality of life between melanoma and non-melanoma skin cancer patients. Eur J Dermatol. 2019;29(2):185-91. https://doi.org/10.1684/ejd.2019.3523.

15. Rieke K, Schmid KK, Lydiatt W, Houfek J, Boilesen E, Watanabe-Galloway S. Depression and survival in head and neck cancer patients. Oral Oncol. 2017; 65:76-82. https://doi.org/10.1016/j.oraloncology.2016.12.014.

16. Tas F, Karabulut S, Guveli H, et al. Assessment of Anxiety and Depression Status in Turkish Cutaneous Melanoma Patients. Asian Pac J Cancer Prev. 2017;18(2):369-73. https://doi.org/10.22034/APJCP.2017.18.2.369.

17. Shah M, Mavers M, Bree A, Fosko S, Lents NH. Quality of life and depression assessment in nevoid basal cell carcinoma syndrome. Int J Dermatol. 2011; 50(3):268-76. https://doi.org/10.1111/j.1365-4632.2010.04658.x

18. Sanderman R, Ranchor AV. The predictor status of personality variables: etiological significance and their role in the course of disease. Eur J Personal. 1997;11(5):359-82. https://doi.org/10.1002/(sici)1099-0984(199712 )11:5<359::aid-per307>3.3.co;2-s.

19. Aarstad HJ, Aarstad AKH, Birkhaug EJ, Bru E, Olofsson J. The personality and quality of life in HNSCC patients following treatment. Eur J Cancer. 2003; 39(13):1852-60. https://doi.org/10.1016/50959-8049(03)00308-3.

20. Nakaya N, Bidstrup PE, Saito-nakaya K, et al. Personality traits and cancer risk and survival based on finnish and swedish registry data. Am J Epidemiol. 2010;172(4):377-85. https://doi.org/10.1093/aje/kwq046.

21. Gogas HJ, Karalexi MA, Dessypris N, Antoniadis AG, Papadopoulos F, Petridou ET. The role of depression and personality traits in patients with melanoma: a south-European study. Melanoma Res. 2017;27(6):625-31. https://doi.org/10.1097/CMR.0000000000000380.

22. Tavakol M, Dennick R. Making sense of Cronbach's alpha. Int J Med Educ. 2011;2:53-5. https://doi.org/10.5116/ijme.4dfb.8dfd.

23. Calderón-Narváez G. Un cuestionario para simplificar el diagnóstico del síndrome depresivo. Revista de Neuro-psiquiatría. 1997;60(2):127-35. https:// doi.org/10.20453/rnp.v60i2.1406.

24. Apalla Z, Lallas A, Sotiriou E, Lazaridou E, Ioannides D. Epidemiological trends in skin cancer. Dermatol Pract Concept. 2017;7(2):1-6. https://doi. org/10.5826/dpc.0702a01.

25. Gordon R. Skin cancer: an overview of epidemiology and risk factors. Semin Oncol Nurs. 2013;29(3):160-9. https://doi.org/10.1016/j.soncn.2013.06.002.

26. Cameron MC, Lee E, Hibler BP, Barker CA, Mori S, Cordova M, et al. Basal cell carcinoma: epidemiology; pathophysiology; clinical and histological subtypes; and disease associations. J Am Acad Dermatol. 2019;80(2):303-17. https://doi.org/10.1016/j.jaad.2018.03.060.

27. Christensen MM, Yousaf U, Engholm G, et al. Increased suicide risk among Danish women with non-melanoma skin cancer, 1971-1999. Eur J Cancer Prev. 2006;15(3):3-268. https://doi.org/10.1097/01.cej.0000195712.64448.ba.
28. Heltoft KN, Slagor RM, Agner T, Bonde JP. Metal arc welding and the risk of skin cancer. Int Arch Occup Environ Health. 2017:90(8):873-81. https://doi. org/10.1007/s00420-017-1248-5.

29. Lichter MD, Karagas MR, Mott LA, Spencer SK, Stukel TA, Greenberg ER. Therapeutic ionizing radiation and the incidence of basal cell carcinoma and squamous cell carcinoma. Arch Dermatol. 2000;136(8):1007-11. https:// doi.org/10.1001/archderm.136.8.1007.

30. Suárez B, López-Abente G, Martínez C, Navarro C, Tormo MJ, Rosso S, et al. Occupation and skin cancer: the results of the HELIOS-I multicenter casecontrol study. BMC Public Health. 2007;7(1):180. https://doi.org/10.1186/14 71-2458-7-180.

31. Holm-Schou ASS, Philipsen PA, Wulf HC. Skin cancer phototype: a new classification directly related to skin cancer and based on responses from 2869 individuals. Photodermatol Photoimmunol and Photomed. 2019;35(2): 116-23. https://doi.org/10.1111/phpp.12432.

32. Kasumagic-Halilovic E, Hasic M, Ovcina-Kurtovic NA. Clinical study of basal cell carcinoma. Med Arch. 2019;73(6):394-8. https://doi.org/10.5455/meda rh.2019.73.394-398.

33. Richmond-Sinclair NM, Pandeya N, Ware RS, Neale RE, Williams GM, van der Pols JC, et al. Incidence of basal cell carcinoma multiplicity and detailed anatomic distribution: Iongitudinal study of an Australian population. J Investig Dermatol. 2009;129(2):323-8. https://doi.org/10.1038/jid.2008.234.

34. Ruetze M, Dunckelmann K, Schade A, Reuschlein K, Mielke H, Weise JM, et al. Damage at the root of cell renewal-UV sensitivity of human epidermal stem cells. J Dermatol Sci. 2011;64(1):16-22. https://doi.org/10.1016/j. jdermsci.2011.06.010.

35. Ziehfreund $\mathrm{S}$, Krause J, Rotter M, et al. Primary and secondary prevention of skin cancer in rural areas: A cross-sectional study in the Bavarian Forest. Der Hautarzt; Zeitschrift fur Dermatologie, Venerologie, und verwandte Gebiete. 2020;71(5):365-73. https://doi.org/10.1007/s00105-020-04566-7.

36. Kasai Y, Sakakibara T, Mizuno T. Characteristics of patients with high lie scores in a personality test. Indian J Psychol Med. 2017;39(4):418-21. https:// doi.org/10.4103/0253-7176.211745.

37. Tanji F, Kakizaki M, Sugawara Y, Watanabe I, Nakaya N, Minami Y, et al. Personality and suicide risk: the impact of economic crisis in Japan. Psychol Med. 2015;45(3):559-73. https://doi.org/10.1017/S0033291714001688.

38. Jokela M, Batty GD, Hintsa T, Elovainio M, Hakulinen C, Kivimäki M. Is personality associated with cancer incidence and mortality? An individualparticipant meta-analysis of 2156 incident cancer cases among 42843 men and women. Br J Cancer. 2014;110(7):1820-4. https://doi.org/10.1038/bjc.2 014.58.

39. Kissen DM, Eysenck HJ. Personality in male lung cancer patients. J Psychosom Res. 1962;6(2):123-7. https://doi.org/10.1016/0022-3999(62)90062-4.

40. García-Torres F, Castillo-Mayén R. Differences in Eysenck's personality dimensions between a Group of Breast Cancer Survivors and the general population. Int J Environ Res Public Health. 2019;16(7):1240. https://doi.org/1 0.3390/ijerph16071240.

41. Uliaszek AA, Zinbarg RE, Mineka S, et al. The role of Neuroticsim and extraversion in the stress-anxiety and stress-depression relationship. Anxiety Stress Coping. 2010;23(4):363-81. https://doi.org/10.1080/1061 5800903377264

42. Buneviciute J, Staniute M, Brozaitiene J, Girdler SS, Bunevicius R. Mood symptoms and personality dimensions as determinants of health-related quality of life in patients with coronary artery disease. J Health Psychol. 2013;18(11):1493-504. https://doi.org/10.1177/1359105312465909.

43. López-Pulido El, Ramírez-De Los Santos S, et al. Association of Obesity with Depressive Symptomatology, Eating Habits, Interleukin-8 and Cortisol in a Young Population. Ecol Food Nutr. 2021;60(3):324-33. https://doi.org/10.1 080/03670244.2020.1845166.

44. Mohammadkhani P, Abasi I, Pourshahbaz A, et al. The role of neuroticism and experiential avoidance in predicting anxiety and depression symptoms: Mediating effect of emotion regulation. Iran J Psychiatry Behav Sci. 2016; 10(3):e5047. https://doi.org/10.17795/ijpbs-5047.

45. Shimizu K, Nakaya N, Saito-Nakaya K, Akechi T, Ogawa A, Fujisawa D, et al. Personality traits and coping styles explain anxiety in lung cancer patients to a greater extent than other factors. Jpn J Clin Oncol. 2015;45(5):456-63. https://doi.org/10.1093/jjco/hyv024.

46. Chow PI, Shaffer KM, Lohman MC, LeBaron VT, Fortuna KL, Ritterband LM Examining the relationship between changes in personality and depression in older adult cancer survivors. Aging Ment Health. 2020;24(8):1237-45. https://doi.org/10.1080/13607863.2019.1594158. 
47. Floyd A, Dedert E, Ghate S, Salmon P, Weissbecker I, Studts IL, et al. Depression may mediate the relationship between sense of coherence and quality of life in lung cancer patients. J Health Psychol. 2011;16(2):249-57. https://doi.org/10.1177/1359105310371856.

48. Mitchell AM, Pössel P, Van Voorhees BW, et al. Associations of depression status and hopelessness with breast cancer: a 24-year follow-up study. J Health Psychol. 2017;22(10):1322-31. https://doi.org/10.1177/135910531562 6998.

49. Moran C, Coroiu A, Körner A. Psychosocial distress in patients with cutaneous melanoma: validation of the skin Cancer index (SCI). Support Care Cancer. 2021;29(2):1005-14. https://doi.org/10.1007/s00520-02005568-w.

50. Sampogna F, Paradisi A, lemboli ML, Ricci F, Sonego G, Abeni D. Comparison of quality of life between melanoma and non-melanoma skin cancer patients. Eur J Dermatol. 2019;29(2):185-91. https://doi.org/10.1684/ ejd.2019.3523.

51. Kuoppasalmi Kl, Lonnqvist JK. Mental disorders and comorbidity in suicide. Am J Psychiatr. 1993;150(6):935-40. https://doi.org/10.1176/ajp.150.6.935.

52. Vaidya TS, Mori S, Dusza SW, Rossi AM, Nehal KS, Lee EH. Appearancerelated psychosocial distress following facial skin cancer surgery using the FACE-Q skin cancer. Arch Dermatol Res. 2019;311(9):691-6. https://doi.org/1 0.1007/s00403-019-01957-2

53. García-Torres F, Alõs FJ. Eysenck personality questionnaire revised psychoticism predicts motivational-somatic symptoms of depression in breast cancer survivors. Psychooncology. 2014;23(3):350-2. https://doi.org/1 $0.1002 /$ pon.3446.

54. Ormel J, Oldehinkel AJ, Brilman El. The interplay and etiological continuity of neuroticism, difficulties, and life events in the etiology of major and subsyndromal, first and recurrent depressive episodes in later life. Am J Psychiatr. 2001;158(6):885-91. https://doi.org/10.1176/appi.ajp.158.6.885.

55. Gelabert E, Navines R, Labad J, et al. The role of personality dimensions, depressive symptoms and other psychosocial variables in predicting postpartum suicidal ideation: a cohort study. Arch Womens Ment Health. 2019;23(4):585-93. https://doi.org/10.1007/s00737-019-01007-w.

56. Su H, Zhou Y, Cao J, et al. The mediating effect of coping style on personality and mental health among elderly Chinese empty-nester: A cross-sectional study. Arch Gerontol Geriatr. 2018;75:197-201. https://doi. org/10.1016/j.archger.2018.01.004

57. Lo MT, Hinds DA, Tung JY, Franz C, Fan CC, Wang Y, et al. Genome-wide analyses for personality traits identify six genomic loci and show correlations with psychiatric disorders. Nat Genet. 2017;49(1):152-6. https:// doi.org/10.1038/ng.3736.

\section{Publisher's Note}

Springer Nature remains neutral with regard to jurisdictional claims in published maps and institutional affiliations.

Ready to submit your research? Choose BMC and benefit from:

- fast, convenient online submission

- thorough peer review by experienced researchers in your field

- rapid publication on acceptance

- support for research data, including large and complex data types

- gold Open Access which fosters wider collaboration and increased citations

- maximum visibility for your research: over $100 \mathrm{M}$ website views per year

At $\mathrm{BMC}$, research is always in progress.

Learn more biomedcentral.com/submissions 